\title{
Low-GWP Refrigerant Evaluation in AC Systems for High Ambient Temperature Applications - Literature Survey for Impact of Varying Refrigerant Charge on AC System Performance - FY18 $1^{\text {st }}$ Quarter Milestone Report
}

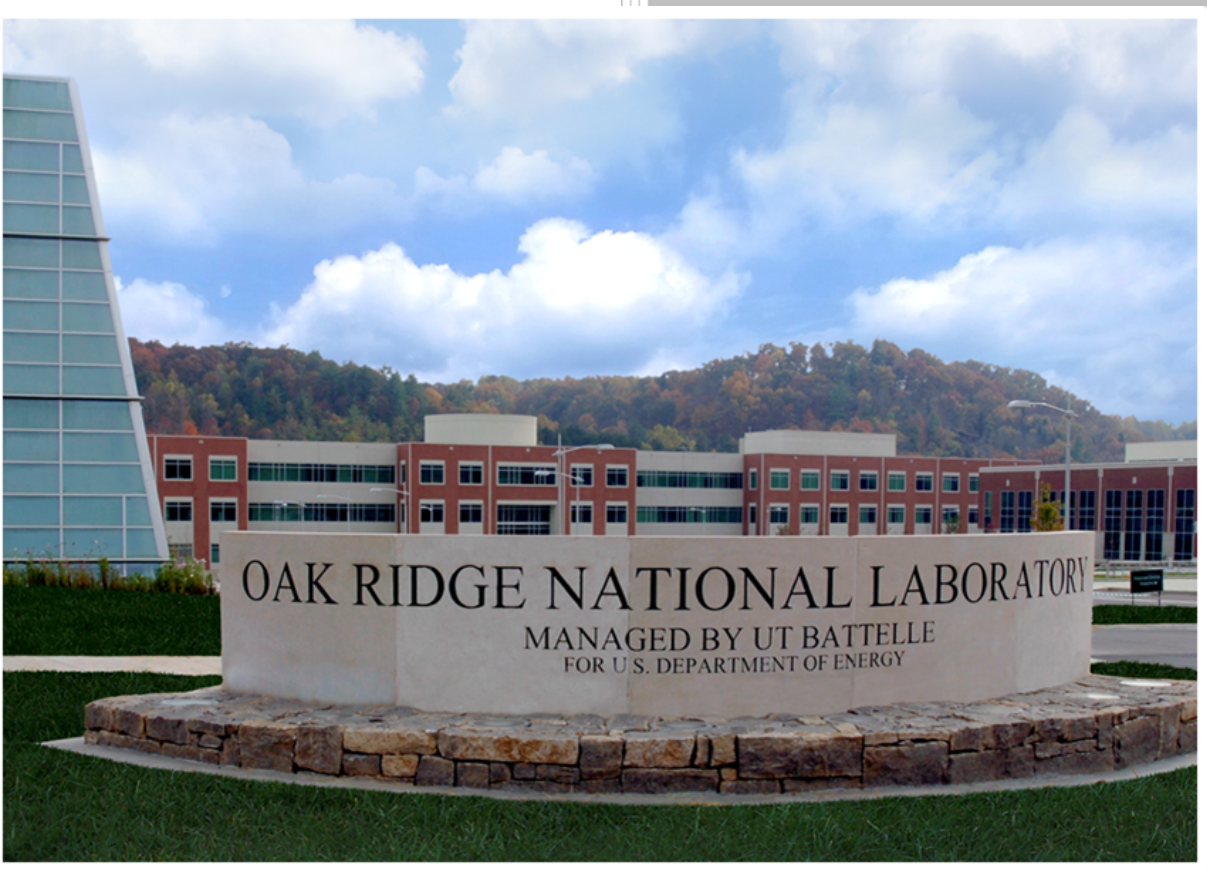

\section{Approved for public release.} Distribution is unlimited.

Bo Shen

$01 / 15 / 2018$ 


\title{
DOCUMENT AVAILABILITY
}

Reports produced after January 1, 1996, are generally available free via US Department of Energy (DOE) SciTech Connect.

Website http://www.osti.gov/scitech/

Reports produced before January 1, 1996, may be purchased by members of the public from the following source:

\author{
National Technical Information Service \\ 5285 Port Royal Road \\ Springfield, VA 22161 \\ Telephone 703-605-6000 (1-800-553-6847) \\ TDD 703-487-4639 \\ Fax 703-605-6900 \\ E-mail info@ntis.gov \\ Website http://www.ntis.gov/help/ordermethods.aspx
}

Reports are available to DOE employees, DOE contractors, Energy Technology Data Exchange representatives, and International Nuclear Information System representatives from the following source:

Office of Scientific and Technical Information

PO Box 62

Oak Ridge, TN 37831

Telephone 865-576-8401

Fax 865-576-5728

E-mail reports@osti.gov

Website http://www.osti.gov/contact.html

This report was prepared as an account of work sponsored by an agency of the United States Government. Neither the United States Government nor any agency thereof, nor any of their employees, makes any warranty, express or implied, or assumes any legal liability or responsibility for the accuracy, completeness, or usefulness of any information, apparatus, product, or process disclosed, or represents that its use would not infringe privately owned rights. Reference herein to any specific commercial product, process, or service by trade name, trademark, manufacturer, or otherwise, does not necessarily constitute or imply its endorsement, recommendation, or favoring by the United States Government or any agency thereof. The views and opinions of authors expressed herein do not necessarily state or reflect those of the United States Government or any agency thereof. 


\title{
BTO Project 3.2.2.19 \\ FY18 $1^{\text {st }}$ Quarter Milestone Report
}

\section{Low-GWP Refrigerant Evaluation in AC Systems for High Ambient Temperature Applications - Literature Survey for Impact of Varying Refrigerant Charge on AC System Performance}

\author{
Author \\ Bo Shen
}

Date: 01/15/2018

Prepared by

OAK RIDGE NATIONAL LABORATORY

Oak Ridge, TN 37831-6283

managed by

UT-BATTELLE, LLC

for the

US DEPARTMENT OF ENERGY

under contract DE-AC05-00OR22725 


\section{Literature Survey for Impact of Varying Refrigerant Charge on AC System Performance (Regular Milestone)}

\section{Executive Summary}

The report summarizes the findings of ASHRAE Research project 1173, by Purdue University to assess the impact of varying refrigerant charge on air conditioner (AC) system performance. This project tested six residential air conditioners with varying the system charge in a wide range, using TXV or fixed-orifice as the expansion device. In summary, the systems using fixed-orifices are much more sensitive to reduction of the system charge than using TXVs. The systems using fixed-orifices had noticeable performance degradations when reducing the system charge below $90 \%$ relative to the factory charge; the systems using TXVs experienced drastic performance penalties when decreasing the system charge below $80 \%$. In the cases, the TXVs were all fully open and couldn't control the target superheat degree. In order to limit the system charge for lower-GWP refrigerants, without degrading the system performance much, the AC systems are recommended to use TXV and compact heat exchangers, i.e. micro-channel heat exchangers.

\section{Impact of Charge Variation in Residential Air Conditioners}

The new lower-GWP refrigerants mostly contain HFO refrigerants (R-1234yf or R-1234ze) and R-32. They are classified as A2L refrigerants, having minor flammability. It is necessary to limit the system charge inventory; sometime, even sacrifice the optimum performance with limiting the system charge to meet the safety regulation. The report summarizes previous studies for the impact of varying refrigerant charge on the system performance of residential air conditioners.

Purdue University [1] [2] conducted comprehensive laboratory investigations to assess impact of varying refrigerant charge on system performance of residential air conditioners. They extensively tested six residential air conditioners with varying the system charge inventory in a wide range. The six units used either thermo-expansion valve (TXV) or fixed-orifice, and covered three refrigerants, i.e. R-410A, R-22 and R-407C. The rated cooling capacities varied from 2.5-ton to 5-ton. They all used fin-and-tube indoor and outdoor heat exchangers. Table below summarizes the unit information.

Table 1: Six Residential AC Units for Varying System Charge

\begin{tabular}{|l|l|l|l|l|l|l|}
\hline Unit & 1 & 2 & 3 & 4 & 5 & 6 \\
\hline Refrigerant & R-410A & R-410A & R-410A & R-407C & R-22 & R-22 \\
\hline Expansion & TXV & Fixed-orifice & Fixed-orifice & Fixed-orifice & Fixed-orifice & TXV \\
\hline Rated capacity & 3-ton & 3-ton & 3-ton & 5-ton & 2.5-ton & 2.5-ton \\
\hline Split or packaged & Split & Split & Packaged & Packaged & Packaged & Packaged \\
\hline
\end{tabular}


When changing the system charge, the units were evaluated at four ambient temperatures, i.e. $75^{\circ} \mathrm{F}, 82^{\circ} \mathrm{F}$, $95^{\circ} \mathrm{F}$ and $115^{\circ} \mathrm{F}$, and two indoor conditions, i.e. Wet $-80^{\circ} \mathrm{F}$ dry bulb $/ 51 \%$ relative humidity; and Dry $80^{\circ} \mathrm{F} / 30 \%$ relative humidity.

Figures 1 illustrates EER ratios at various charge levels, relative to the EER obtained at the $100 \%$ system charge, having the same outdoor and indoor conditions. The $100 \%$ system charge (nominal level) was the factory charge recommended by the equipment manufacturer. Figures 2 illustrates capacity ratios relative to the air side capacity obtained at the $100 \%$ system charge, the same outdoor and indoor conditions.

It can be seen, the systems using fixed-orifices as the expansion device are much more sensitive to reduction of the system charge than using TXVs. In general, the systems using fixed-orifices had noticeable performance degradations when reducing the system charge below $90 \%$ relative to the factory charge; the systems using TXVs experienced drastic performance penalties when decreasing the system charge below $80 \%$. In the cases, the TXVs were fully open and couldn't control the target superheat degree.

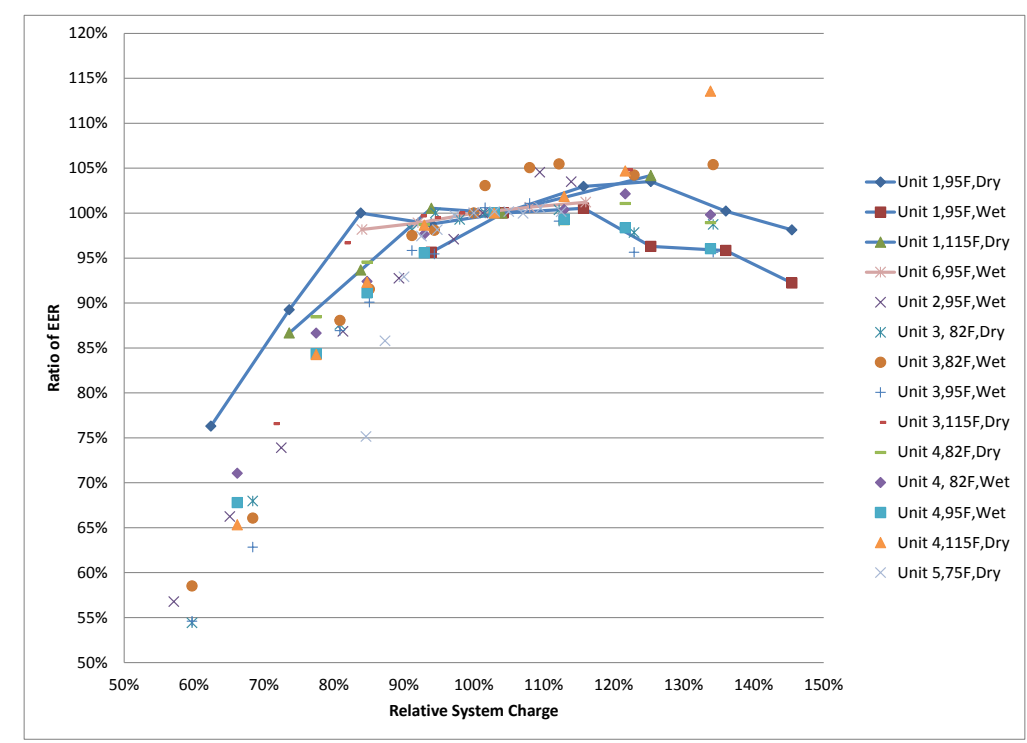

Figure 1: EER ratios as function of relative system charge in six residential AC units

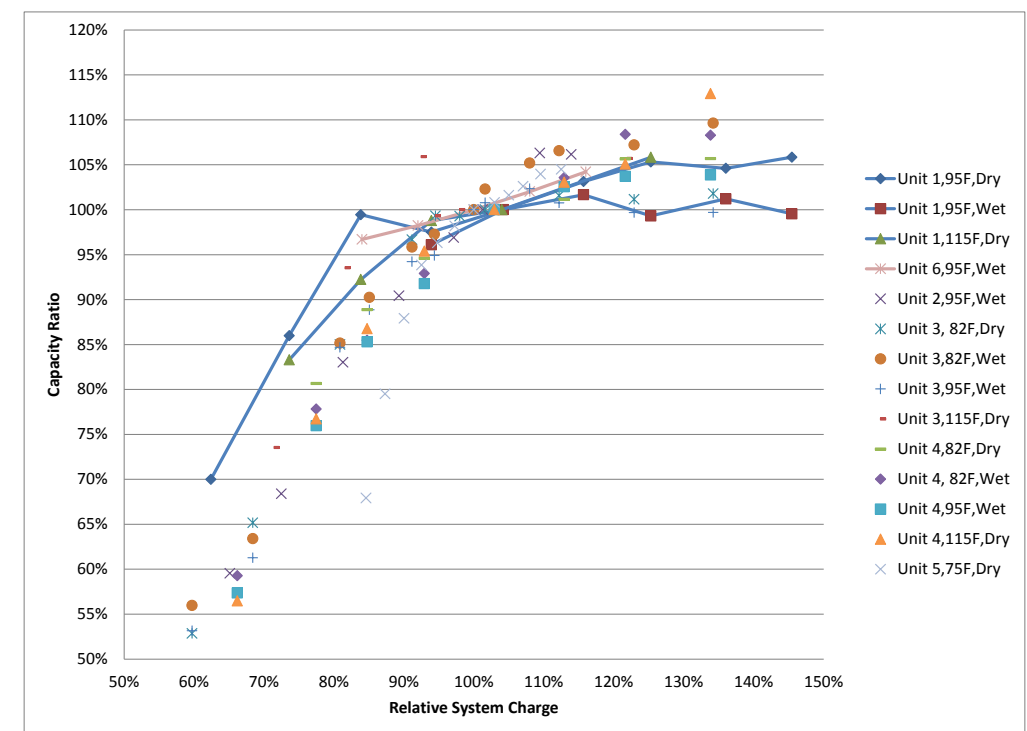

Figure 2: Capacity ratios as function of relative system charge in six residential AC units 


\section{References}

[1] Bo Shen, EA Groll, JE Braun, 2006, Improvement and validation of unitary air conditioner and heat pump simulation models for R-22 and HFC alternatives at off-design conditions, - Final Report for ASHRAE Research Project 1173, 2006, Purdue University, West Lafayette, IN.

[2] Bo Shen, James E. Braun, Eckhard A. Groll, Improved methodologies for simulating unitary air conditioners at off-design conditions, International Journal of Refrigeration, Volume 32, Issue 7, 2009, Pages 1837-1849, ISSN 0140-7007. 